\title{
THE INFLUENCE OF SOCIO-ECONOMIC SITUATION IN THE REGIONS OF THE NORTH CAUCASUS FEDERAL DISTRICT OF THE RUSSIAN FEDERATION ON THE SOURCES OF TERRORIST CRIMES
}

\section{Feofilova T. Yu. ${ }^{1}$ and Alekseeva Yu. A。 ${ }^{2}$}

${ }^{1}$ St. Petersburg Polytechnic University of Peter the great, candidate of economic sciences, Associate Professor, St. Petersburg, Russia

${ }^{2}$ St. Petersburg Polytechnic University of Peter the great, Student 2 masters course of the Graduate School of public and financial management, St. Petersburg, Russia

\section{Abstract}

it was found that over the past 5 years a number of crimes of a terrorist nature

Corresponding Author:

Alekseeva Yu. A.

susieswanson@yandex.ru

Received: 11 December 2017

Accepted: 20 January 2018

Published: 13 February 2018

Publishing services provided by Knowledge $\mathrm{E}$

\section{(c) Feofilova T. Yu. and}

Alekseeva Yu. A.. This article is distributed under the terms of the Creative Commons

Attribution License, which permits unrestricted use and redistribution provided that the original author and source are credited.

Selection and Peer-review under the responsibility of the FinTech and RegTech: Possibilities, Threats and Risks of Financial Technologies Conference Committee.

\section{S OPEN ACCESS} has greatly increased. The hypothesis appeared that the adverse socio-economic situation creates conditions for the growth of crimes of a terrorist nature. As a result, the analysis revealed an inverse relationship between the "actual final consumption per person in thousand rubles", average cash income per month in thousand rubles and the number of crimes of a terrorist nature.

Keywords: socio-economic development, crimes of a terrorist nature, region, NorthWest Federal District

\section{Introduction}

Foreign economic and geopolitical factors have adversely affected the socio-economic situation in Russia and its regions [4, 32]. For the period from 2014 to 2017, the problem of terrorism at the international and national levels became critical; an increase in the number of crimes of extremist nature in regions, the problem of money laundering and corruption is still actual. The hypothesis of this study is that adverse change of quantitative and qualitative indicators of socio-economic development of regions creates conditions for the commission of criminal acts of terrorist and extremist nature.

\section{Materials and methods}

Application of methods of statistical analysis revealed the dynamics of values of indicators of socio-economic development of the North-West. 


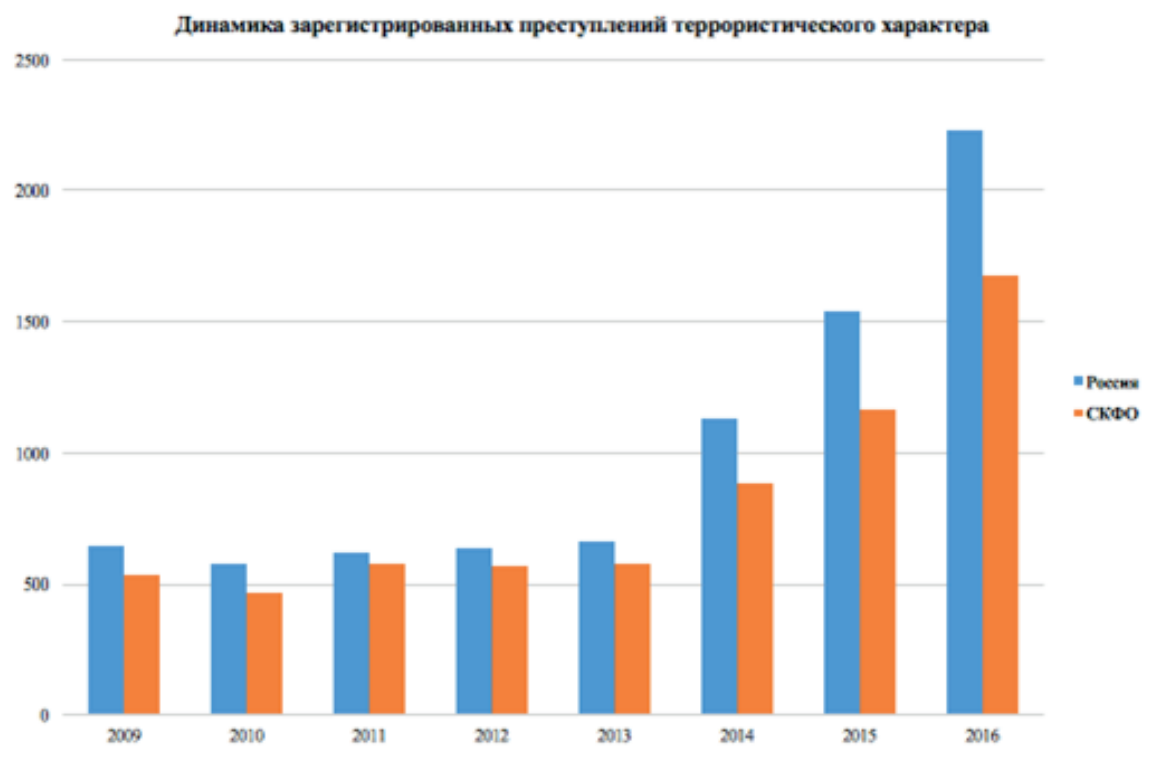

Figure 1: Dynamics of recorded crimes of a terrorist nature.

Using correlation analysis has led to obtaining the result of the presence of feedback between socio-economic status of the region and the number of crimes of a terrorist nature.

This information was taken from specialized sources. Empirical basis was taken from data of the Federal State statistics service and the Office of the General Prosecutor of the Russian Federation.

\section{Discussion}

Choice of the North Caucasus Federal District (hereinafter referred to as the NORTH) as an object of study is due to the large share of NORTH CAUCASIAN FEDERAL DISTRICT in reported crimes of a terrorist nature happened in Russia, in 2016, their specific weight is of $75 \%$. (Figure 1 )

As a result of analysis of data of the Prosecutor General of the Russian Federation, it was found that from 2009 to 2016 the growth rate of the number of registered crimes of a terrorist nature in the North-West Federal District (310\%) match the tempo of growth (340\%) in the Russian Federation as a whole.

Data analysis of the Federal State Statistics Service showed that the NWFD takes the last place in the ranking of the constituent entities of the Russian Federation on the basic of socio-economic indicators from 2011to 2015. For example, it takes the last place in ranking of all taxes on income in the budget system of the Russian Federation 
on a per capita basis, the level of employment, as well as the number of recorded crimes per 100000 inhabitants.

A study on the socio-economic situation was carried out based on time-series analysis $[1,16]$ indicators: actual final consumption per person, the gross regional product per capita, average per capita cash income per month, the proportion of employed persons, as well as terrorist offences in the period from 2010 to 2015 in Russia (table 1).

TABLE 1: Trends in the indicators of socio-economic development of the NORTH-WEST for 2010-2015 Gg.

Indicators
Actual final consumption per
person, thousand rubles.
GRP per capita, thousand rubles.
Money income, thousand rubles.
The share of people employed, $\%$
The number of crimes of a terrorist
nature

\begin{tabular}{|l|l|l|l|l|l|}
\hline 2010 & 2011 & 2012 & 2013 & 2014 & 2015 \\
\hline 128.5 & 149.5 & 171.5 & 191.2 & 207.7 & 228.4 \\
\hline 39.1 & 95.0 & 112.6 & 127.0 & 146.1 & 164.9 \\
\hline 13.3 & 15.1 & 17.2 & 18.9 & 20.7 & 23.0 \\
\hline 35.28 & 35.65 & 35.70 & 35.79 & 35.99 & 35.78 \\
\hline 464 & 576 & 565 & 579 & 883 & 1168 \\
\hline
\end{tabular}

From Table 1 it can be seen that in 2015 in comparison to 2010.

- actual final consumption in 2015 , increased by 99.9 thousand rubles or $77.7 \%$. However, in prices of 2009 actual final consumption has changed less significantly by 30.6 thousand rubles (or $23.9 \%$ ), i.e., the absolute increase in the month totaled 2.55 thousand rubles.

- GROSS REGIONAL PRODUCT per capita rose to 125.8 thousand rubles or $321,7 \%$. While the greatest increase was in 2011 in comparison with 2010, absolute 55.9 thousand rubles in relative is $143.0 \%$. However, in prices of 2009 , the picture is less optimistic, $193.9 \%$ growth or 75.81 thousand rubles per year, i.e. an increase of the average expression was 6.3 thousand rubles per month;

- the absolute growth of average per capita money income totaled 9.7 thousand rubles or $72.9 \%$. While in 2015 in comparison with 2014 the value of the analyzed indicator increased by 2.3 thousand rubles in comparison with the previous year, or $11.1 \%$ on. Along with this, the prices of 2009 revenues grew only for 2.3 thousand rubles (to 16.03 thousand rubles per month) or $20.5 \%$;

- an absolute increase of crimes of a terrorist nature is 704 or $151.7 \%$. The most significant increase in crisis in 2014 and 2015. Therefore, in 2014 as compared to 
2013 the quantity increased by 304 registered crimes or 52.5\% in 2015, 2011, the absolute increment compared with 2014 amounted to 285 crimes or $32.3 \%$;

- the share of employed in the period was at 35\%, the growth rate of $1.4 \%$.

To identify the close relationship between indicators characterizing socio-economic situation in the region $[1,36]$, and the number of recorded crimes of a terrorist nature, a correlation analysis was done (Table 2 ).

TABLE 2: Tight connection between the values of indicators characterizing socio-economic situation in the region and the number of recorded crimes of a terrorist nature.

\begin{tabular}{|l|c|c|c|c|}
\hline Growth rates, $\%$ & $\begin{array}{c}\text { Actual final } \\
\text { consumption per } \\
\text { person, thousand } \\
\text { rubles. }\end{array}$ & $\begin{array}{c}\text { GRP per capita, } \\
\text { thousand rubles }\end{array}$ & $\begin{array}{c}\text { Average cash } \\
\text { income per } \\
\text { month, thousand } \\
\text { rubles }\end{array}$ & $\begin{array}{c}\text { The share of } \\
\text { people } \\
\text { employed, \% }\end{array}$ \\
$\begin{array}{l}\text { The number of } \\
\text { crimes of a } \\
\text { terrorist nature }\end{array}$ & -0.72 & 0.01 & -0.75 & 0.1 \\
\hline
\end{tabular}

Thus, it was revealed that between GRP per capita and number of crimes of a terrorist nature there was no relationship. There is a poor link to the proportion of employed persons. However, it has been established that between "actual final consumption per person in thousand rubles, average cash income per month in thousand rubles and the number of recorded crimes of a terrorist nature was closely connected. That is, improving the quality of life of its citizens decreases the level of crimes of a terrorist nature. In our opinion, the lack of links between the GRP per capita and share of employed due to the fact that the values of these indicators are practically have not changed did not have a significant impact on the socio-economic situation in the NWFD.

\section{Conclusion}

In conclusion, it should be noted that the results of the study confirmed the hypothesis that was formulated. It allows drawing a conclusion of the lack of capacity of public administration in the Russian Federation subjects, which are not allowed to form conditions for dynamic positive socio-economic development of the regions.

\section{References}

[1] Bazar V. R. Korreliacionno - regressionnyj analysis -jekonomicheskih social'no svjazi s ispol'zovaniem faktorov programmy uchebnoe posobie Excel. Melbourne: GOU 
VPO "UGTU-UPI, $2009.102 \mathrm{~s}$.

[2] Oficial'nyj RF prokuratury General'noj sajt. URL: http://www. genproc.gov.ru

[3] Oficial'nyj sajt Federal'noj gosudarstvennoj sluzhby RF statistiki. URL: http://www.gks.ru

[4] Feofilova T.J. Sovremennoje sostojanije regionov: k voprosy ob ocenke jekonomicheskoj bezopasnosti. Spb.: SPBGEU, 2016. S. 32-35. 